\title{
Probiotik sebagai Pengatur Komposisi Gut microbiota dalam Menghambat
}

\section{Progresivitas Parkinson's Disease}

\author{
Ahmad Taufik Fadillah Zainal*, Andi Muh. Aunul Khaliq G, A. Fitri Febrianty \\ Program Studi Sarjana Kedokteran, Fakultas Kedokteran, Universitas Hasanuddin, Makassar \\ *Correspondence: ahmadtaufik2014004@gmail.com
}

\begin{abstract}
ABSTRAK
Latar Belakang: Penyakit Parkinson (Parkinson's Disease/PD) adalah salah satu penyakit neurodegeneratif yang paling banyak terjadi pada usia 40-70 tahun. Dewasa kini, gangguan pada GutMicrobiota-Brain Axis telah dihubungkan dengan produk metabolit bakteri yang berperan pada terjadinya neuroinflamasi. Memahami secara tepat peranan dari proses neuroinflamasi pada Parkinson Disease (PD) dapat membawa pemahaman terhadap bagaimana PD timbul dan kaitannya dengan mikroba usus (Gut Microbiota/GM). Tujuan: Untuk mengetahui efektivitas probiotik sebagai target terapi untuk menghambat progresivitas PD. Metode: Literature review ini disusun menggunakan metode studi pustaka dengan mengumpulkan referensi yang valid mengenai GM dan PD serta hubungan antar keduanya. Pembahasan: Bukti uji coba in vivo menggunakan tikus AlphaSynuclease-Overexpressing (ASO) dilaporkan bahwa Dysbiosis Gut Microbiota dapat menyebabkan terjadinya inflamasi dengan mekanisme pengaktifan sel mikroglia dan peningkatan sitokin proinflamasi yang dimodulasi oleh produk metabolit Short Chain Fatty Acids (SCFAs) yang mengarahkan pada terjadinya agregasi alpha-Synuclein ( $\alpha$ Syn) dan berujung pada progresivitas PD. Salah satu mikroba yang mengalami penurunan jumlah pada Dysbiosis Gut Microbiota adalah Lactobacillus rhamnous $G G$ (L-GG), yang memiliki peran neuroprotektif dalam menghambat progresivitas PD. Intervensi berbasis Microbiota-targeted dengan metode penggunaan probiotik LGG telah menunjukkan efek positif pada penghambatan progresivitas PD. Kesimpulan: Dysbiosis GM memiliki jalur yang mampu meningkatkan progresivitas dari penyakit parkinson. Hal ini mampu dimanfaatkan sebagai target terapi, rekayasa komposisi mikroba dengan metode pemberian probiotik L-GG menjadi solusi dalam menghambat progresivitas PD dengan mengembalikan efek neuroprotektif dari L-GG.
\end{abstract}

Kata Kunci: alpha-Synuclein (aSyn), Gut Microbiota (GM), Lactobacillus rhamnous GG (L-GG), Parkinson Disease (PD), Short Chain Fatty Acids (SCFAs)

\begin{abstract}
Background: Parkinson's Disease (PD) is one of the most common neurodegenerative diseases at the age of 40-70 years. Disorders of the Gut-Microbiota-Brain Axis have been linked to bacterial metabolite products that play a role in the occurrence of neuroinflammation. Understanding precisely the role of the neuroinflammatory process in PD can lead to an understanding of how PD occurs and its relation to gut microbiota (GM) Objectives: To determine the effectiveness of probiotics as a therapeutic target to inhibit the progression of PD. Methods: Literature study method by collecting valid references regarding $G M$ and $P D$ and the relationship between them. Discussion: Evidence from in vivo trials using Alpha-Synuclease-Overexpressing ( $\alpha$ Syn) mice reported that Dysbiosis GM can cause inflammation by activating microglia cells and increasing proinflammatory cytokines modulated by metabolite products of Short Chain Fatty Acids (SCFAs) which lead to the occurrence of alpha-Synuclein aggregation and leads to the progression of PD. One of the microbes that have decreased the number of Dysbiosis GM is Lactobacillus rhamnous GG, which has a neuroprotective role in inhibiting the progression of PD. Microbiota-targeted interventions using the probiotic L-GG method have shown a positive effect on inhibiting PD progression. Conclusion: GM dysbiosis caused
\end{abstract}


by PD has a pathway that can increase the progression of PD. This can be used as a therapeutic target, microbial composition engineering with the method of giving $L-G G$ probiotics to be a solution in inhibiting the progression of $P D$ by restoring the neuroprotective effect of $L-G G$.

Keywords: alpha-Synuclein (aSyn), Gut Microbiota (GM), Lactobacillus rhamnous GG (L-GG), Parkinson's Disease (PD), Short Chain Fatty Acids (SCFAs)

Received [15 Aug 2020]| Revised [4 May 2021] | Accepted [26 Aug 2021]

\section{PENDAHULUAN}

\section{Penyakit Parkinson (Parkinson's Disease/PD)}

Penyakit Parkinson (Parkinson's Disease/PD) adalah salah satu penyakit neurodegeneratif yang paling banyak terjadi pada usia 40-70 tahun dan mencapai puncak pada dekade 6 . Prevalensi dari PD yaitu sekitar 160 per 100.000 populasi. Penyakit Parkinson lebih banyak pada pria dengan rasio pria dibandingkan wanita yaitu $3: 2 .^{[1]}$ Dalam beberapa penelitian $\mathrm{PD}$, penyakit ini akan meningkat seiring bertambahnya usia. ${ }^{[2]}$

Penyakit ini menyebabkan beban berat bagi penderita yang terkena dampak, serta keluarga penderita. Dari sudut pandang motorik, PD ditandai oleh suatu sindrom klinis yang dikenal secara luas sebagai asparkinsonisme, yang meliputi empat fitur utama: bradikinesia, tremor istirahat, kekakuan, dan gangguan postur. Selain itu, PD juga bermanifestasi pada non motorik penderita seperti: insomnia, dispepsia, konstipasi, hingga depresi. Manifestasi non motorik inilah yang dapat menyebabkan penurunan kualitas hidup penderita. $^{[3]}$

Penyakit Parkinson terjadi karena adanya penurunan kadar dopamin yang masif diakibatkan oleh kematian neuron di substansia nigra pars kompakta (SNpc). Respon motorik yang abnormal disebabkan oleh penurunan neurotransmiter dopamin yang sifatnya progresif. Kerusakan progresif lebih dari $60 \%$ pada neuron dopaminergik substansia nigra merupakan faktor dasar munculnya penyakit parkinson. ${ }^{[4]}$

Dopamin merupakan salah satu neurotransmitter utama di otak yang memiliki banyak fungsi berbeda di susunan saraf. Ada 3 kelompok neuron utama yang mensintesis dopamin yaitu substansia nigra (SN), area tegmentum ventral (VTA) dan nukleus hipotalamus. Selain itu, terdapat kelompok neuron yang lebih kecil lagi adalah bulbusolfaktorius dan retina. ${ }^{[4]}$

Neuron dari SN akan berproyeksi ke sriatum dan merupakan jalur yang paling masif mencapai $80 \%$ dari seluruh sistem dopaminergik otak. Proyeksi dari VTA memiliki 2 jalur yaitu jalur mesolimbik dan jalur mesokortikal. Jalur yang menuju sistem limbik yang berperan pada regulasi emosi disebut jalur mesolimbik, sedangkan jalur yang menuju korteks prefrontal disebut jalur mesokortikal. Neuron dopaminergik hipotalamus akan membentuk jalur tuberinfundibular yang memiliki fungsi mensupresi ekspresi dari prolactin. ${ }^{[4]}$

Substansia nigra mengandung sel yang berpigmen (neuromelamin) yang memberikan gambaran "black appearance" (makroskopis). Pada penyakit Parkinson sel ini akan hilang sehingga substansia nigra menjadi berwarna pucat. Sel yang tersisa mengandung inklusi atipikal eosinofilik pada sitoplasma "Lewy bodies". Komponen struktur utama dari Lewy bodies yaitu alpha-synuclein. ${ }^{[5]}$ Alphasynuclein adalah protein neuronal yang diekspresikan secara berlebihan yang menjadi pusat perhatian dalam memahami suatu kelompok gangguan neurodegeneratif yang disebut $\alpha$ synucleinopathies, yang ditandai dengan adanya agregasi alpha-synuclein intraseluler. Penyakit Parkinson termasuk dalam A-synucleinopathies primer. ${ }^{[6]}$

Terdapat dua jenis reseptor dopamin, yaitu D1 (merangsang) dan D2 
(menghambat), yang mempengaruhi aktivitas motorik pada sistem ekstrapiramidal. ${ }^{[7]}$ D1 akan mengaktifkan adenilsiklase sehingga efeknya akan memperkuat signal transmisi postsinaptik. Reseptor dopamin D1 lebih dominan dibanding D2, sedangkan D2 lebih memainkan peranan di striatum. ${ }^{[4]}$

\section{Mikrobiota Usus (Gut Microbiota/GM)}

Saluran gastrointestinal manusia (GI) merupakan salah satu tempat terbesar (250-400 $\mathrm{m}^{2}$ ) yang menghubungkan antara manusia, faktor lingkungan, dan antigen dalam tubuh manusia. Sekitar 60 ton makanan melewati saluran GI manusia bersama dengan berbagai mikroorganisme dari lingkungan yang menimbulkan ancaman besar pada integritas usus. Sekumpulan bakteri, archaea dan eukaryota yang berada pada saluran GI disebut mikrobiota usus. ${ }^{[8]}$

Hubungan antara mikrobiota usus dan kesehatan manusia semakin diketahui lebih luas. GM yang sehat sebagian besar bertanggung jawab atas kesehatan manusia secara keseluruhan. Dari penelitian yang telah dilakukan, hasilnya bahwa mikrobiota usus manusia terdiri dari lebih dari 35.000 spesies bakteri. ${ }^{[9]}$

Mikrobiota usus memberikan banyak manfaat bagi manusia, seperti memperkuat integritas usus atau membentuk epitel usus, melindungi terhadap patogen dan mengatur imunitas. Namun, ada potensi di mana mekanisme ini menjadi terganggu yaitu terjadinya ketidakseimbangan komposisi dari mikrobiota yang dikenal sebagai dysbiosis. ${ }^{[8]}$

Sekarang ini GM sedang marak diperbincangkan di kalangan peneliti, terutama kaitannya dengan gangguan saraf. Ketidakseimbangan dari GM inilah yang akan menyebabkan timbulnya penyakit yang menyerang sistem saraf manusia.

METODE
Literature review ini disusun
menggunakan metode studi pustaka
dengan mengumpulkan referensi yang
valid mengenai gut microbiota dan

Parkinson Disease serta hubungan antar keduanya.

\section{PEMBAHASAN}

\section{Gut Microbiota Brain Axis}

Gut microbiota brain axis adalah komunikasi dua arah antara CNS dan saluran pencernaan yang melibatkan jalur saraf, mekanisme imun dan endokrin. Komunikasi dua arah ini meliputi sistem saraf pusat, otak dan medula spinalis, serta sistem saraf otonom.

Pada manusia, interaksi antara mikrobiota intestinal dan otak telah terbukti sejak 20 tahun lalu pada pasien ensefalopati hepatik setelah pemberian antibiotik oral mengalami perbaikan. Prinsip utama mekanisme komunikasi dua arah gut-microbiota-axis diantaranya (1) produksi, ekspresi, dan pemecahan neurotransmiter (seperti serotonin, GABA) serta faktor neurotropik Brain Derived Neutrotropic Factor (BDNF), (2) proteksi dari barier intestinal dan integritas tightjuction, (3) modulasi dari sinyal aferen sistem saraf enterik, (4) metabolit bakteri, dan (5) regulasi sistem imun mukosal. ${ }^{[10]}$

\section{Aktivasi Mikroglia oleh Metabolit Bakteri}

Salah satu produk utama dari metabolisme bakteri adalah Short Chain Fatty Acid (SCFAs) yang mampu memodulasi aktivasi dari sel imun yang mendiami sistem saraf pusat yaitu mikroglia. Menurut hasil penelitian yang dilakukan Sampson et al. ditemukan adanya pengaruh SCFA pada reaksi inflamasi jaringan saraf yang dimediasi oleh mikroglia. Pada regio otak yang dipengaruhi (caudoputamen dan subtansia nigra) terjadi perubahan morfologi dari mikroglia. Sampson et al. dalam 
penelitiannya, membandingkan tikus yang telah diinduksi PD dan disterilkan mikroba ususnya/Germ Free (GF) dan tikus yang telah diinduksi PD tanpa mengintervensi mikroba ususnya/Specific pathogen free (SPF) kemudian menilai hubungannya dengan aktivitas mikroglia terhadap induksi overekspresi alpha-synuclein. Hasilnya, menunjukkan bahwa tikus yang mikroba ususnya disterilkan dan diinduksi overekspresi alpha synuclein/Germ Free Alpha-Synucleid Overexpression (GFASO) secara signifikan mengalami peningkatan diameter yang disertai penurunan panjang dan jumlah cabang, dibandingkan dengan Germ Free WildType (GF-WT) (Gambar 1A, 1B). Peningkatan aktivasi mikroglia berkontribusi terhadap reaksi inflamasi jaringan saraf ditandai dengan adanya peningkatan sitokin pro-inflamasi yaitu Tumor Necrosing Factor (TNF- $\alpha$ ) dan interleukin-6 (IL-6) pada jaringan homogen di caudoputamen SCFA-ASO dibandingkan dengan tikus GF-ASO (Gambar 1C). Kedua sitokin tersebut diketahui meningkat di otak pasien PD. ${ }^{[11]}$ Hal ini membuktikan bahwa metabolit dari mikroba pada penderita PD memiliki efek terhadap neuroinflamasi.

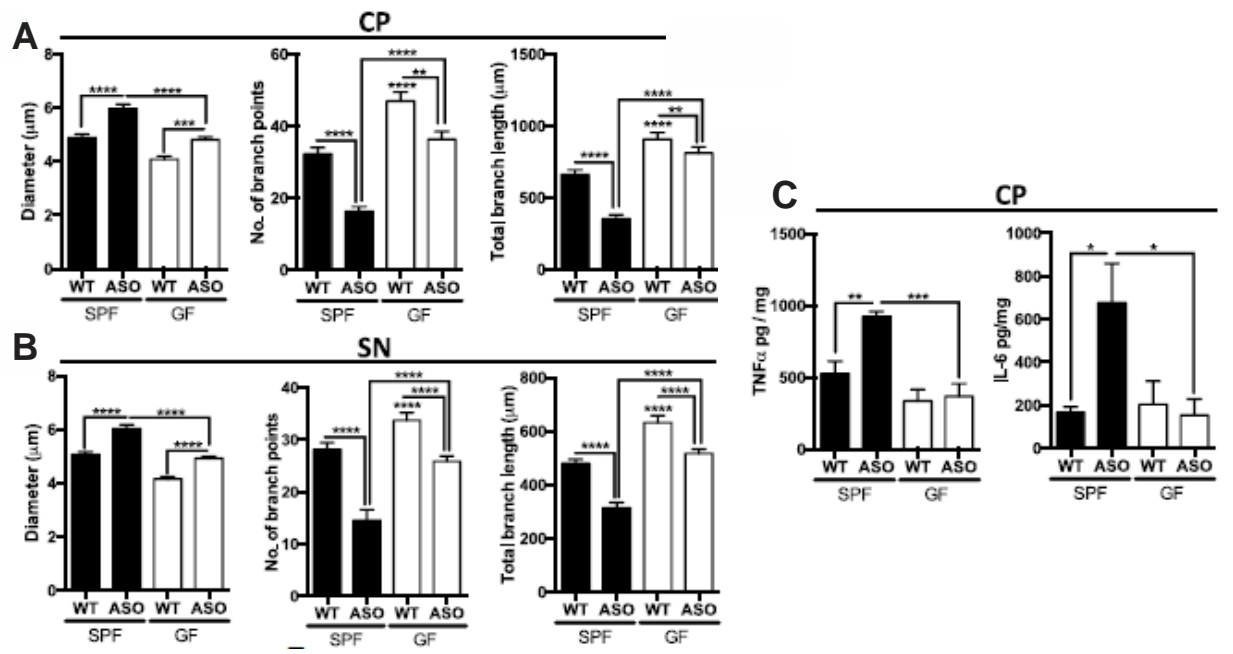

Gambar 1. A) Gambaran mikroglia pada regio caudoputamen B) Gambaran mikroglia pada substansia nigra; terhadap induksi overekspresi alpha-synuclein $(\mathrm{n}=3-4 ; * \mathrm{p}<0.05 ; * * \mathrm{p}<0.01$; $* * * \mathrm{p}<0.001 ; * * * * \mathrm{p}<0.0001 . \mathrm{SPF}$, specific-pathogen-free; GF, germ-free; WT, wild-type; ASO, Thy1a-synuclein genotype).

\section{Reaksi Inflamasi Saraf terhadap Agregasi Alpha-Synuclein}

Terjadinya peningkatan aktivitas mikroglia yang disebabkan oleh metabolit bakteri dan diproduksinya sitokin proinflamasi mengubah fungsi saraf dan meningkatkan kematian sel pada model $\mathrm{PD}^{[12]}$ Hal yang cuku penting adalah kondisi inflamasi ini pula dapat meningkatkan proses agregasi $\alpha$ synuclein, yang selanjutnya kembali dapat meningkatkan aktivasi dari mikroglia hingga terbentuknya kaskade umpan balik yang mengarah kepada pekembangan penyakit parkinson. ${ }^{[13]}$ Telah dilaporkan adanya korelasi positif antara durasi penyakit dan marker pada mikroglia yang teraktivasi dengan jumlah deposisi $\alpha$ synuclein pada subtansia nigra otak manusia postmortem. ${ }^{[12]}$ Peningkatan agregasi alpha-synculein ini akan meningkatkan progresivitas PD dengan merusak bagian dari SNpc.

\section{Disbiosis Gut Microbiota pada Penyakit Parkinson}

Kondisi disbiosis mikrobiota terhadap fungsi otak pada penyakit parkinson dihubungkan oleh gut-microbiota-brain axis. Faktor yang mempengaruhi 
komposisi dari mikrobiota pada manusia di antaranya diet dan infeksi. Keduanya mengarah pada perubahan abnormal dari metabolit bakteri, salah satunya SCFAs yang dapat menginduksi proses inflamasi dan penurunan fungsi barier intestinal (leaky gut). Leaky gut mengakibatkan translokasi komponen patogen dari bakteri
Lipopolisakarida (LPS) dan komponen SCFA, dari mukosa intestinal menuju ke sirkulasi sistemik dan melewati sawar darah otak yang mengaktifkan sistem imun innate khususnya mikroglia yang mengakibatkan reaksi inflamasi saraf. Mekanisme ini mengarahkan pada

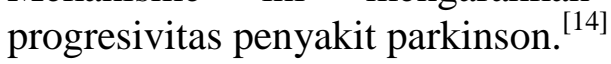
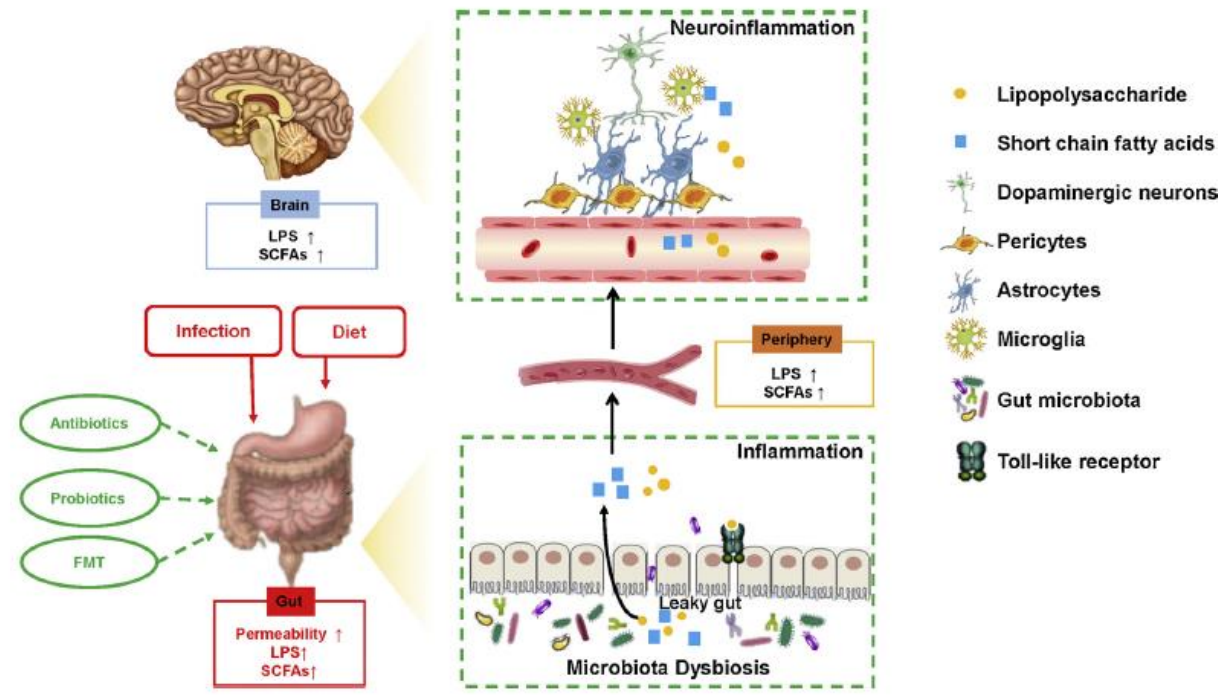

Gambar 2. Skema pengaruh disbiosis mikrobiota usus terhadap parkinson disease.

Pada suatu penelitian ditemukan penurunan jumlah dari Lactobacillus rhamnous yang dianggap memiliki pengaruh terhadap penurunan produksi sitokin proinflamasi yang mampu memberikan efek neuroprotektif serta mampu menghambat progresivitas penyakit parkinson. Sehingga, penurunan jumlah dari L. rhamnous dianggap berefek buruk pada progresivitas penyakit parkinson.

\section{Rekayasa Gut Microbiota (GM) dalam Menurunkan Kejadian Neuroinflamasi.}

Kaitan antara GM dan penyakit parkinson saat ini menarik banyak perhatian, beberapa penelitian saat ini sedang meneliti metode terapi dengan mengintervensi mikroba pada saluran pencernaan dengan harapan mampu menghambat progresivitas dari penyakit parkinson. Pada feses penderita penyakit parkinson ditemukan dysbiosis gut microbiota, peningkatan beberapa mikroba tertentu dan penurunan mikroba Lactobacillus rhamnous $G G$ (L-GG) ya

ng diduga memiliki pengaruh terhadap antineuroinflamasi. Sun, et al. dalam penelitiannya melakukan rekayasa gut microbiota dengan melakukan transplantasi fecal microba/fecal microbiota transplantation (FMT) dari feses tikus yang normal ke hewan uji, perlakuan FMT ini bertujuan untuk memperbaiki komposisi mikroba pada usus tikus yang menderita penyakit parkinson. Tikus sebagai hewan uji yang digunakan diinduksi PD dengan pemberian 1-methyl-4-phenyl-1,2,3,6tetrahydropyridine (MPTP) intraperitoneal $(30 \mathrm{mg} / \mathrm{kg})$ selama 5 hari. Hasilnya, menunjukkan bahwa perlakuan MPTP + FMT secara signifikan mampu menurunkan marker inflamasi TLR4 / TBK1 / NF-jB / TNF- $\alpha$ pada striatum dibandingkan dengan perlakuan MPTP + 
PBS (pemberian gliserol steril 20\%) (Gambar 3). Artinya, intervensi FMT mampu menurunkan kejadian inflamasi pada striatum yang merupakan bagian otak yang mengatur kerja motorik. Perbaikan komposisi mikroba usus juga dipercayai bisa menurunkan sintesis SCFA yang memicu aktivasi mikroglia, sehingga dapat mencegah agregasi alpha-synuclein yang meningkatkan progresivitas motor deficit pada penyakit parkinson. Dalam arti lain, rekayasa mikroba mampu memberikan hasil yang menjanjikan dalam menghambat progresivitas PD. ${ }^{[14]}$
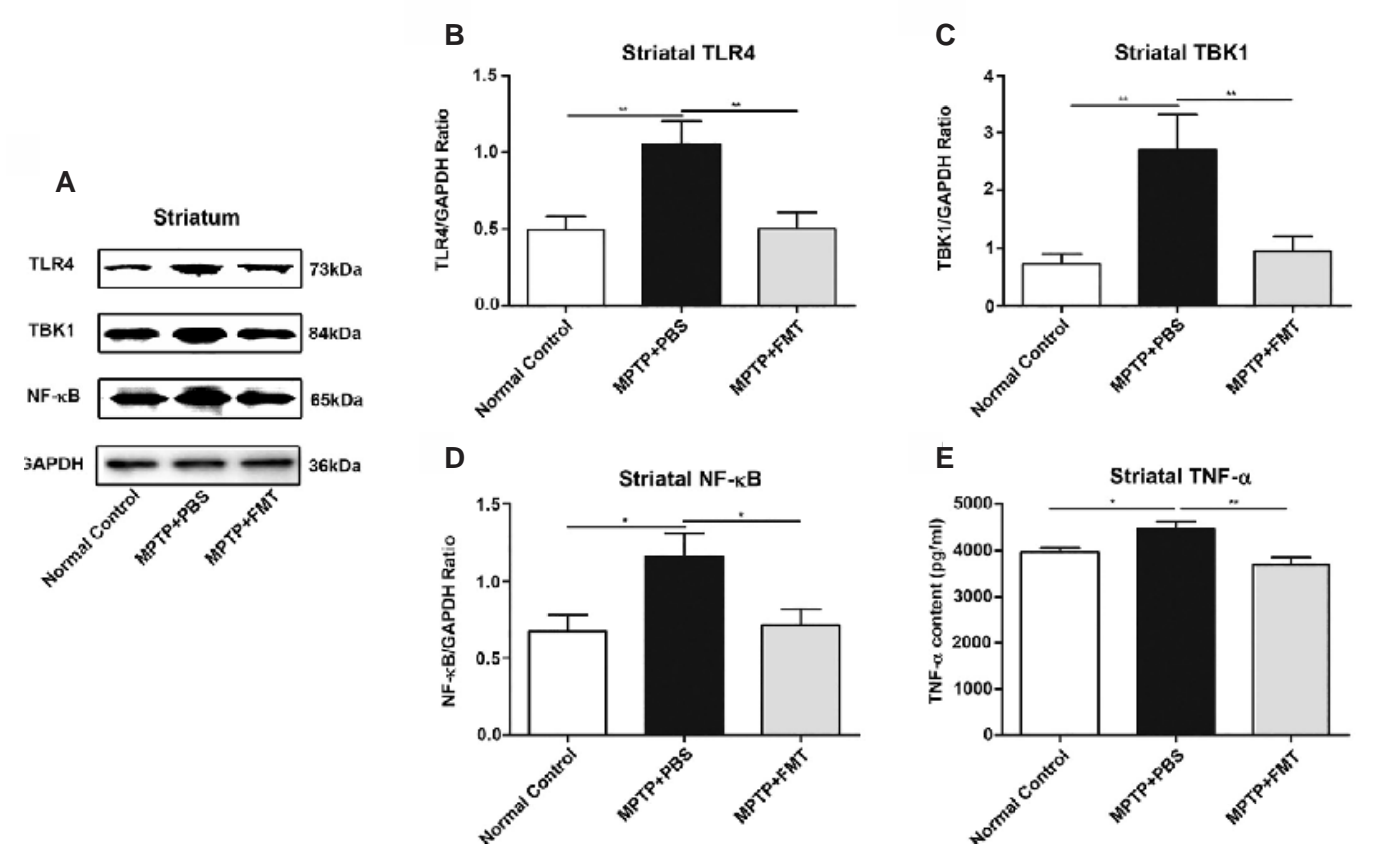

Gambar 3. A) Tampakan menilai Western blott pada striatum yang menilai marker inflamasi (TLR4, TBK1, NF-kB, GAPDH); B) Rasio TLR4/GADPH; C) Rasio TBK1/GAPDH; D) Rasio NF${ }_{k}$ B/GAPDH; E) Kadar TNF- $\alpha$, pada striatum terhadap perlakuan MPTP+BPS, MPTP+FMT dan kontrol normal. ( $\mathrm{n}=6-8$ tikus, $* \mathrm{p}<0,05, * * \mathrm{p}<0,01)$

Penggunaan Probiotik sebagai Pengatur Komposisi Mikroba dalam Menghambat Progresivitas Parkinson's Disease.

Srivastav et al. pada penelitiannya juga mencoba menggunakan rekayasa mikroba usus pada tikus yang PD dengan induksi MPTP pemberian probiotik Lactobacillus rhamnous $G G$ (L-GG) selanjutnya dinilai pengaruhnya terhadap motorik tikus dengan stride length test forelimb, cylinder test, beam traverse test dan challenge beam test pada hari ke- 2 dan ke-6 perlakuan. Hasilnya, menunjukkan bahwa tikus yang telah diinduksi PD kemudian diberikan perlakuan berupa probiotik L-GG secara signifikan memiliki kerja motorik yang lebih baik dibandingkan dengan tikus yang tidak diberikan probiotik L-GG $(\mathrm{p}<0,05)$ (Gambar 4). Hal ini menunjukkan bahwa perbaikan komposisi mikroba usus (GM) dengan pemberian probiotik Lactobacillus rhamnous $G G$ (L-GG) mampu mengembalikan efek neuroprotektif dari L-GG yang berdampak pada penghambatan progresivitas PD. ${ }^{[15]}$ 

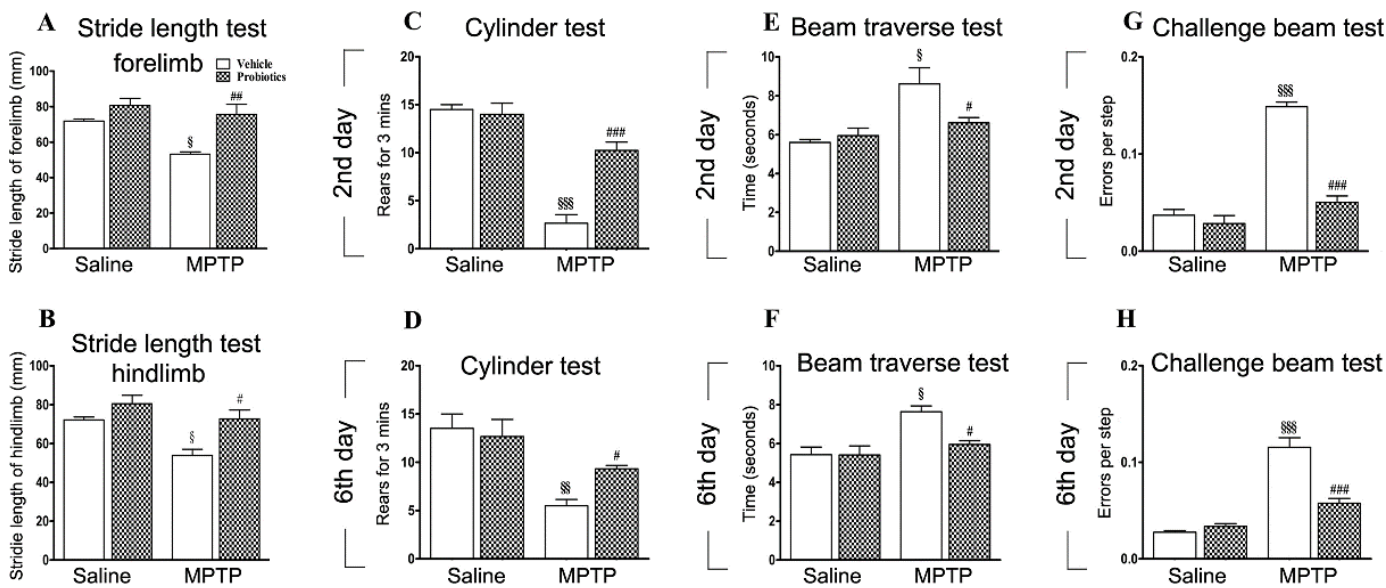

Gambar 4. A,B) Uji stride length test forelimb C,D) Uji cylinder test E,F) Uji beam traverse test $\mathrm{G}, \mathrm{H})$ Uji challenge beam test; pada hari ke-2 dan ke-6 perlakuan. ( $\mathrm{n}=3-4$ per kelompok; $9 \mathrm{~g}$ $<0,01 ;$ g९g $<0,001 ; \# \mathrm{p}<0,05, \# \# \mathrm{p}<0,01, \# \# \# \mathrm{p}<0,0001)$

\section{KESIMPULAN}

Hubungan antara mikroba pada saluran pencernaan gut microbiota dan CNS saat ini semakin menunjukkan titik terang. Beberapa penelitian menunjukkan bahwa ketidakseimbangan komposisi mikroba pada saluran pencernaan dysbiosis gut microbiota mampu meningkatkan progresivitas dari penyakit parkinson. Hal ini mampu dimanfaatkan sebagai target terapi, rekayasa komposisi mikroba dengan metode pemberian probiotik Lactobacillus rhamnous GG (LGG) menjadi solusi dalam menghambat progresivitas PD dengan mengembalikan efek neuroprotektif dari L-GG.

\section{SARAN}

Selaku penulis, kami menyarankan untuk dilakukan penelitian lebih lanjut terhadap pemberian probiotik Lactobacillus rhamnous $G G$ (L-GG) pada penderita PD dan menilai efek samping dari pemberian probiotik tersebut.

\section{DAFTAR PUSTAKA}

[1] Muliawan, E., Jehosua, S., Tumewah, R. Diagnosis Dan Terapi Deep Brain Stimulation Pada
Penyakit Parkinson. Jurnal Sinaps 2018 Vol. 1 No. 1 , hlm. 67-84.

[2] Tysnes, O., Strostein, A. 2017. Epidemiology of Parkinson's disease. Neurology And Preclinical Neurological Studies - Review Article. 2017

[3] Massano, J., Bhatia, K. Clinical Approach to Parkinson's Disease:Features, Diagnosis, and Principles of Management. Cold Spring Harbor Laboratory Press. 2015

[4] Gunawan, G., Dalhar, M., Kurniawan, S. Parkinson Dan Terapi Stem Sel. MNJ, (2017) Vol.03, No.01.

[5] Koutoudis, Ted K. Parkinson's Disease. Emedicine Health. [Internet]. Diakses 6 Juni 2013. Available from: http://www.emedicinehealth.com/par kinson_disease/article_em.htm

[6] Kim, W. S., Kågedal, K., \& Halliday, G. M. Alpha-synuclein biology in Lewy body diseases. Alzheimer's Research \& Therapy, 2014. 6(5-8).

[7] Demaagd, G., Pharm., Philip, A. Parkinson's Disease and Its Management. P\&T. 2015. Vol. 40; No.8; 504-8 
[8] Thursby, E., Juge, N. Introduction to the human gut microbiota. Biochemical Journal. 2017. 474 1823-1836.

[9] Jandhyala, S., Talukdar, R., Subramanyam, C., Vuyyuru, H., Sasikala, M., Reddy, D. Role of the normal gut microbiota. World Journal of Gastroenterology. 2015

[10] Carabotti M, Scirocco A, Antonietta $\mathrm{M}$, Severi C. The gut-brain axis: interactions between enteric microbiota, central and enteric nervous systems. 2015;203-9.

[11] Sampson TR, Debelius JW, Thron T, Wittung-stafshede P, Knight R, Mazmanian SK, et al. Gut Microbiota Regulate Motor Deficits and Neuroinflammation in a Model of Parkinson, $s$ Disease. 2016;1469-80.

[12] Kannarkat GT, Boss JM. The Role of Innate and Adaptive Immunity in Parkinson 's Disease. 2013;3:493514.

[13] Gao, X., Carroni, M., NussbaumKrammer, C., Mogk, A., Nillegoda, N. B., Szlachcic, A. Bukau, B. Human Hsp70 Disaggregase Reverses Parkinson's-Linked $\alpha$ Synuclein Amyloid Fibrils. Molecular Cell. 2015, 59(5), 781-793.

[14] Sun M, Shen Y. Dysbiosis of gut microbiota and microbial metabolites in Parkinson 's Disease. Ageing Res Rev [Internet]. 2018;45(April):53-61.

[15] Srivastav, S., Neupane, S., Bhurtel, S., Katila, N., Maharjan, S., Choi, H., Choi, D.-Y. Probiotics mixture increases butyrate, and subsequently rescues the nigral dopaminergic neurons from MPTP and rotenoneinduced neurotoxicity. 2019. The Journal of Nutritional Biochemistry. 